\title{
Southeast Asian Adaptations of the Ramayana and their Use in the Indonesian-Malaysian Shadow Play with Special Reference to Characterization
}

\author{
Ghulam-Sarwar Yousof, Cultural Centre, University of Malaya, \\ Kuala Lumpur, Malaysia \\ gsyousof@um.edu.my \\ (C) 2015 University of Malaya. All rights reserved. \\ Malaysian Journal of Performing and Visual Arts, Volume 1, 2015
}

\begin{abstract}
The Ramayana may be encountered in several versions in Southeast Asia, demonstrating significant variations as well as mutual influences within the region itself and also further appropriations when it comes to the vast diversity of performing arts active in the region. Apart from significant shifts in plot as well as interpretations of the Ramayana, particularly through attempts to localize it, one of the most fascinating areas in which transformations have taken place is characterization. The present paper will examine characterization within the epic in two examples of the shadow play - the Indonesian wayang kulit purwa and the Malaysian wayang kulit Kelantan.
\end{abstract}

Key Words: Ramayana, wayang kulit purwa, wayang kulit Kelantan, Hikayat Maharaja Wana, shadow play, Indonesian shadow play, Malaysian shadow play

\section{Introduction: Southeast Asian adaptations of the Ramayana}

The significant differences in the texts as well as performances of the Ramayana in Southeast Asia strongly indicate that the epic reached countries in the region from several different locations in India, the principal ones in the region being the Old Javanese Ramayana Kekawin by Yasadipira, Serat Kanda, Hikayat Seri Rama and the Thai Ramakien. ${ }^{2}$ Serat Kanda provided most of the source material for the present-day classical Indonesian shadow play, wayang kulit purwa, as well as for the Ramayana-based dance theatre. The main sources of dramatic repertoire for the Malaysian shadow play, wayang kulit Kelantan, are the literary Hikayat Seri Rama and the oral Hikayat Maharaja Wana with some influences from the Patani version of the epic from southern Thailand. In addition, the Javanese created their own stories based on the Mahabharata or by combining materials from the Ramayana and the Mahabharata, while shadow play puppeteers (dalang) of wayang kulit purwa as well as wayang kulit Kelantan also developed secondary or extension stories, known as lakon carangan in Indonesia and cerita ranting in Malaysia using non-epic material or their own imagination.

Without going into details it may be summarized that versions of the story of Rama mentioned above are characterized by differences in terms of plot, setting, and characterization in attempts to localize the epic. In the current discussion a character-approach is adopted, allowing for movement between relevant versions of the Ramayana in wayang kulit purwa and wayang kulit Kelantan, these being the most important genres, respectively, in Indonesia and Malaysia.

\section{General Characteristics}

In general terms, while the basic plot structures of the epics remain near-identical, there are significant differences between the versions mentioned. Leaving aside language, technical or literary details, as well 
as spiritual or religious values, the following are noteworthy characteristics: (a) the shortening or simplification of plots; (b) localization of the events, (c) changes or shifts in the presentation of the figures in the events depicted; and (d) the inclusion of new characters into the narratives used for performances.

The large numbers of characters, major and minor, in the Malay shadow play can be divided, for the sake of convenience, into several groups, ranging from gods and demons through human beings to mixedbreed characters and animals. In the present context only Dewa Sang Yang Tunggal from among the gods, two maharisi figures, Seri Rama, Laksmana and Sita Dewi from among the noble characters, Maharaja Wana (Rawana) from the category of demons and Semar as well as Pak Dogol, both regarded as godclowns, will serve to demonstrate how transformations in characterization have been brought into performances of the two genres selected for this study. ${ }^{3}$

\section{Mythology}

The mythology of the Indonesian and Malay versions of the Ramayana, where it does exist, is less complex and considerably different from that of the principal Indian versions. In the first instance, although gods are occasionally mentioned, few of them are actually involved in events developed in puppeteers' (dalang) narratives. Hindu values and teachings are rarely indicated or totally omitted, with emphasis placed strongly upon events and comedy sequences, particularly in wayang kulit Kelantan, a folk form of theater compared to the classical wayang kulit purwa. Where the essential story of the epic moves into the stage of performances in the form of guides (pakem) in Java for the puppeteers (GhulamSarwar, 1994: 203), Malaysian puppeteers depend entirely upon memory, improvising upon basic outlines of plots handed down orally.

In Indonesian mythology stories connected with the genesis of gods and their involvement in human affairs, especially when presented in the shadow play are highly elaborate while in Kelantan they are straightforward, watered down rarely known even to puppeteers (dalang). In both instances, the opening scenes are located in the sky country (Kayangan), an upper world far different from any in Hinduism. Through a rather complex process there takes place the descent to earth of Dewa Sang Yang Tunggal, the ruler of Kayangan. He assumes the form of the god-clown Semar. Kelantanese puppeteers have a strong conviction that Semar manifested himself as Pak Dogol, the senior comic figure in their version of shadow play. With Semar there are his three companions (punakawan), Gareng, Petruk and Bagong, while Pak Dogol creates for himself a companion, Wak Long out of his own body dirt (daki). In both Javanese and Malaysian shadow play the comic figures belong neither to the inherited corpus of Hindu myths nor to the Ramayana. In Kelantan as in the Southern Thai nang talung, lesser comic figures have been independently developed, at times modeled upon living persons. In recent decades with the encroachment of orthodox Islam upon Indonesian-Malay life, Semar has been given an Islamic character or mystical meanings. This has not happened to Pak Dogol, although it is evident that Semar and Pak share many characteristics including deformity and ugliness which serve as deliberate means to disguise their true identities and appearances, allowing them to maintain humility. Semar serves the Pandawa brothers of the Mahabharata, while Pak Dogol is servant first to Rawana and later to Seri Rama.

In Javanese wayang stories which maintain the theme of Vishnu's reincarnation, the god descends to the lower world several times in human form including Arjunasasrabahu, (for a brief period), Rama (renamed Ramawijaya),) Krishna (renamed Kresna) and Arjuna. Arjunasasrabahu and Arjuna, the second and fourth reincarnations, are not included in the Vaishnava system of divine manifestations (avatara). In the Indonesian wayang madya Vishnu also reincarnates as Brawijaya, the raja of Kediri. As in the Mahabharata, both the Krishna and the Arjuna incarnations occur simultaneously in wayang kulit purwa. In wayang kulit Kelantan, Vishnu is subsumed within the more human than divine character of Dewa Berembun, who reincarnates as Seri Rama, son of Sirat Maharaja (Dasaratha) in the land of Siusia Mendarapura. 


\section{Maharisi Characters}

Belonging to the brahmin caste, sage characters have central roles in both Hindu Indian sacred literature as well as religious practices. A significant number of such figures, including Vashishta, Viswamitra and Gautama, play vital roles at various stages in the story of Rama. While present in Indonesian and Malay versions of the epic, in keeping with overall changes the maharisi figures have undergone significant transformations, particularly in their appearance in theatre. In Kelantanese wayang kulit such characters have suffered diminution due to the dilution or removal of religious and spiritual elements, in consonance with revisions brought into the epic itself. Two sage figures, however, stand out - Maharisi Burung Jerejit and Maharisi Mata Api.

Maharisi Burung Jerejit, a meditating saint, is a striking and highly significant figure who has neither a name nor a direct role within the Ramayana story as it unfolds on the wayang kulit Kelantan screen (kelir). His designation refers to the fact that a pair of honey birds (burung jerejit) have built a nest in his beard during his extended period of meditation. By creating an artificial wife, Siti Cendana, out of sandalwood, Maharisi Burung Jerejit becomes the parent of Dewi Anjani, Raja Bali and Sagariwa, only to discover that his two sons were, in fact, born as a result of Siti Cendana's secret liaisons, respectively, with the Sun god, Dewa Matahari and the moon god, Dewa Bulan. They are turned into monkeys, while the daughter, cursed by Siti Cendana, turns into stone, and eventually becomes the mother of Hanuman Kera Putih. The story relating the birth of the three children does not appear in wayang kulit purwa.

Maharisi Burung Jerejit comes into wayang kulit Kelantan in a sequence of activities following the ritual opening of the theatre (buka panggung). He conducts certain additional rites to cleanse and bless the theatre, before introducing a pair of minor deities with arrows (dewa panah), who perform a symbolic battle of negative versus positive forces. This marks the beginning of the prologue (bahagian dalang $m u d a$ ) presented by a junior puppeteer. After the exit of the dewa panah and Maharisi Burung Jerejit, several further sections of the prologue ensue. The highlight is the introduction of Seri Rama, which will presently be discussed.

Maharisi Mata Api, also named Maharisi Kala and Maharisi Kala Api, lives at Wat Tujuh Kedi Bermas. ${ }^{4}$ He discovers Sita Dewi as a newborn child floating on the waters and takes her home to his wife, Minuram Dewi; the couple adopt her. Maharisi Mata Api immediately plants forty palm trees (pokok lontar) in a row, as well as a sejati jawa tree in preparation for the competition (sayembara) for Sita Dewi's hand. Nothing further is mentioned about him until it is time for the competition. Seri Rama succeeds in shooting the arrows through the forty trees. Accompanied by his two servants, Endeng and Epong, Maharisi Mata Api then sets out to personally invite his guests to the wedding. The marriage, however, does not take place as Seri Rama decides to leave Wat Tujuh Kedi Bermas with Sita Dewi even before the Maharisi returns. Upset, Maharisi Mata Api predicts misfortune for the couple.

At a later stage in the plot Maharisi Mata Api plays a vital role when Sita Dewi is sentenced to death by Seri Rama following the discovery of a portrait of Rawana in her possession, as presented in the episode entitled Siti Dewi Dihalau or Cerita Kusi Serawi. Since Laksmana, who is appointed her executioner, is unable to kill her, Sita Dewi returns to Maharisi Kala's hermitage. There she gives birth to a son, Kusi. The Maharisi creates a second child, Serawi, out of lemon grass (serai). With the exception of Tulsidas' Ramcharitmanasa, Sita Dewi's exile is not featured in major Indian versions of the Ramayana.

It is clear that in the two sages, Kelantanese puppeteers have fused two different characters from Hindu mythology. Maharisi Burung Jerejit is developed upon the character of Gautama, whose wife Ahalya is seduced by the god Indra (Harshananda, 2012: 58), while Maharisi Mata Api, is modeled upon the sageking Janaka to create a "generic" hermit figure, depicted as an old and extremely wise person sporting a beard, with a walking stick (tongkat), and occasionally with a string of beads. In terms of characterization there is little to distinguish one maharisi from the other, and indeed in wayang kulit Kelantan performances the same puppet represents both. 


\section{The Protagonists}

In the case of wayang kulit Kelantan significant changes have taken place in the early conduct of the principal characters. Instead of the generally accepted story of the descent of Vishnu from the heavens to punish Rawana for his misdemeanors, there is now the story of Dewa Bota Serajuk, Dewa Berembun and his wife, Siti Andang Dewi. Dewa Bota Serajuk, a demon (bota, from Skt bhuta) or raksasa, has long desired the beautiful Siti Andang Dewi. He vows that if he ever has the opportunity to possess her, he would leave Kayangan. He attains his desire when, disguised as Dewa Berembun, he manages to ravish Siti Andang Dewi. Satisfied, Dewa Serajuk voluntarily descends to earth in self-exile. Disgusted at having been polluted, Siti Andang Dewi does the same; Dewa Berembun also leaves the heavens following the sense of shame and disgrace. They are eventually born on earth, respectively, as Rawana or Maharaja Wana, Sita Dewi and Seri Rama. This, then, is a different story in which the major Hindu deities have no role as in Indian versions of the Ramayana. Since the three descend to earth voluntarily, there is no reason for any "punishment" of Dewa Serajuk by any deity.

In some ways this is an interesting re-interpretation of the Ramayana, with a significant shift in its principal religious theme. The plot of the epic, as used in the Kelantan shadow play, has to do with "personal" issues rather than with a conflict of any sort involving gods and demons. There is no banishment involved in the case of Dewa Serajuk ${ }^{5}$, and the exile of all the three principal characters from Kayangan, the scene of the crime, so to speak, is voluntarily undertaken although perpetrated in the first place by obnoxious and immoral conduct on the part of Dewa Bota Serajuk. Few other characters appear in the opening episodes, and the characters in Kayangan do not even suggest any need for a reincarnation. The three principal figures leave their heavenly abode out of pride in the case of Dewa Serajuk and feelings of disgrace and shame on the part of the two others. There is no suggestion whatsoever that their story will continue on earth with any kind of revenge, or end in a cataclysmic battle between good and evil forces. It just happens. So this version of the Ramayana is an adventure story, rather than a tale possessing moral, spiritual or religious dimensions. This is the situation in Malaysia. In Indonesia the motive for the descent and the potential revenge are more clearly developed in line with classical Indian versions of the Ramayana, but with some interesting new interpretations of events as well as characters.

\section{Maharaja Wana}

From his arrival on earth begin the adventures of Rawana as chief of the demons as well as ruler of Langkapuri. He marries creatures of numerous species and has strange mixed-breed progeny with them. His children include the following. Gangga Maha Sura with the dragon or snake princess (Puteri Naga); Pahlawan Gajah Sumor with the white elephant, (Gajah Putih Betina); Belang Raja Rimau with the tiger princess Harimau Betina Putih Belang Tujuh; Raja Lebis Ira Bumi with Tuan Puteri Maya Bumi, who is descended from the tribe of Jin; Mah Inderajit with Tuan Puteri Seludang Mayang from the Kayangan; Tuan Puteri Mata Api with the Pari princess in the jungle, named Tuan Puteri Pari; and Jin Maula Tani also with Tuan Puteri Maya Bumi, the Jin princess. Rawana's relationships or extensive affairs with the many species of creatures is something local rather than Indian or Indonesian. His progeny helps him populate the world and to rule it unchallenged until his dismal fall at the hands of Seri Rama.

Traditionally the story goes that, having thus firmly established himself as king, Rawana desires a "normal" wife. He goes to Siusia Mendarapura to demand that Sirat Maharaja's wife Mandodari, be handed to him. Sirat Maharaja found Mandodari in a bamboo grove while opening up land to build his capital city. Rawana's demand connects up neatly with an important theme: Rawana's obsession with Sri Lakshmi reveals a facet of his character perhaps unknown outside Indonesia. To appreciate this story, we need to take a step or two backwards.

Indonesian Ramayana stories tell of Rawana's strength and power reaching to the level when he is able to threaten the very gods in Kayangan. In one of these tales when he is on the point of invading the sky 
country, literally at the "doors of heaven", he demands that Sri, or Lakshmi, wife of Vishnu, be handed over to him. In a compromise settlement the gods offer him three heavenly nymphs (bidadari), Dewi Tari, Dewi Aswani and Dewi Triwati. Rawana accepts them, but indicates that this is only a temporary arrangement, and that his pursuit of Lakshmi will go on in her future incarnations on earth. Rawana marries Betari Tari, Aswani/Kiswani is married to Kumbhakarna, and Dewi Triwati to Wibhisana.

On one occasion Rawana meets Dewi Widawati, daughter of Wersapati, who is an incarnation of Lakshmi. He proposes to her, she rejects him and when he forces himself on her, she commits suicide by burning herself. He regrets what has happened, becomes intensely frustrated, but even more determined to attain his goal. His next target, Dewi Chitrawati, is the daughter of Chitradarma, king of Magada. Many kings come to propose to her, but are rejected, because she has hopes of marrying an incarnation of Vishnu. When a thousand rejected kings attack Magada, Arjunasasra, defeats them in battle, and marries Chitrawati. When, next, Rawana launches an attack to capture Chitrawati, Arjunasasra destroys the forces of Lanka and arrests Rawana. Rawana asks Kala Marica to spread the news that Arjunasasra has fallen in the war. Hearing that, Chitrawati kills herself with all her palace maids; she is later revived by Arjunasasra.

The next step in Rawana's mission brings him into the principal plot of the Ramayana. In Indonesian versions of the epic, Dasaratha's first wife, Kausalya (renamed Dewi Sukasalya) is the daughter of Banapatra, the king of Ayodhya, who rums away with Rawatmaja on her father's advise due to the fear that Rawana will want to marry her. Coming to know of this, Rawana kills Banaputra. Sukasalya finds refuge with Dasaratha, a rishi wandering about in the forests. He engages in battle with Rawana. Betara Guru creates an exact replica of Dewi Sukasalya from a flower, and hands her over to Rawana who takes her home with him. When she returns to her original form as a flower and transcends to heaven, Rawana attacks Kayangan where he meets the god Indra, and demands that Dewi Sri be handed over to him. This is rejected and in the ensuing conflict, Rawana manages to capture Wiswakarma, the heavenly architect and his daughter, Dewi Sayempraba. Rawana marries Sayempraba and her father is forced to become architect of Rawana's palace in Lanka.

In wayang kulit Kelantan the same incident is present in a simpler fashion. Maharaja Wana desires a beautiful woman as a wife after all the strange creatures with which he has had liaisons and progeny. He comes to know of the kingdom of Siusiamendarapura, of its king, Sirat Maharaja (Dasaratha), and of that king's beautiful wife, Mandodari. He then decides to go to get her. Sirat Maharaja is unable to do anything, and so agrees to hand over Mandodari after several days. Mandodari creates an imitation of herself from her own body-dirt (daki) and the clone, named Mandodaki is sent off with Rawana to Lanka. She becomes the mother of Sita Dewi.

\section{Sita Dewi}

All the reincarnations of Dewi Sri/Lakshmi in fact lead to Sita Dewi. The earlier events in the life of Rama and Sita are well known in variations of the Ramayana wherever it has spread. During the time when Rama and Sita Dewi are in the forest of Dandaka, following the mutilation of Rawana's sister, Surpanakha (in Malaysia Siti Mayang), Rawana goes into the forest both to avenge the harsh treatment of Siti Mayang as well as to take a look at Sita Dewi since Siti Mayang has aroused his interest by telling him of Siti Dewi's beauty. His passion is aroused immediately he sees her, for in her he recognizes a manifestation of Dewi Sri. This leads to his kidnapping of Sita Dewi and the fulfillment of the prophecy that her birth would bring disaster upon Rawana. She is in fact his own abandoned daughter set afloat on the waters on the advise given by Rawana's astrologer brother, Wibhisana (Mah Babu Sanam).

From the very onset, Sita Dewi's character has been presented in diverse fashion. In Valmiki's Ramayana she is found by the childless King Janaka of Mithila, when personally performing a religious ceremony involving the ploughing of the land. Janaka accepts the baby as a gift of the earth to him. In the Kelantan 
version, she is the daughter of Rawana and Mandodaki, the imitation Mandodari handed to Rawana by Sirat Maharaja as mentioned above. In the Indonesian Serat Rama by Ki Yasadipura she is a normal person, in Kitab Ramayana she is said to have been born from the earth, whereas Parwacarita indicates that Sita Dewi is the daughter of Rawana with Dewi Tari, one of three nymphs (bidadari) given by Narada to Rawana when the demon king attacks Kayangan. Then again there is the key idea that she is the reincarnation of Dewi Sri. ${ }^{6}$

In terms of plot development, the rest of the story is more or less consistent in the two versions under consideration here, with details varying considerably in the manner of presentation by puppeteers both in Java and Kelantan. For instance, in wayang kulit Kelantan there occurs an important scene unknown in Indonesian versions. This involves the incident in which Sita Dewi is caught red handed with a portrait of Rawana, and ordered by Seri Rama to be killed; Laksmana is to be her executioner. Saved by the gods, she returns to the hut of her adopted father, Maharisi Mata Api. It is clear that this incident involving the banishment of Sita has a parallel in the Ramcharitmanasa of Tulsidas without, of course, the incident involving the portrait, the origins of which must be traced to other sources. In the various versions of the Ramayana two examples of this story are found - that in the Uttara Kanda or Lava Kusha Kanda of Tulsidas, and in the wayang kulit Kelantan.

Then there comes the final scene, once again somehow found in both Ramcharitmanasa and wayang kulit Kelantan but with vast differences. In the former, following the birth of Lava and Kusha and their reunion with their father, Sita Dewi returns to the womb of mother earth whence she first emerged, swallowed in a dramatic and triumphant departure. In wayang kulit Kelantan, in a unique retelling of the episode in Siti Dewi Dihalau, following the adventures of her sons, when Kusi and Serawi meet Seri Rama, he realizes that Sita Dewi is still alive. Then comes the reconciliation and marriage of Rama and Sita. In general, Sita's character remains little changed throughout the various versions of the Ramayana as she remains a passive heroine. This sees a significant change in Tulsidas' final kanda and in the wayang kulit Kelantan episode just mentioned. Having, in general, discarded the religious, philosophical and moral tones of the epic, local coloring has brought in what may be regarded as Malay customary conduct. This is a trend encountered too in the other Southeast Asian countries where the epic remains an important source for the development of scripts or scenarios for the region's many traditional theatre genres. Beyond that, outside the frame of the core Ramayana story, and following Siti Dewi Dihalau, Sita Dewi becomes an active heroine in the wayang kulit Kelantan's branch (ranting) stories, inspired by episodes from the Javanese Panji romances.

\section{Seri Rama}

The basic role of Seri Rama or Rama as well as his characterization remain essentially unchanged in most Southeast Asian versions of the Ramayana including the two under discussion here. Wayang kulit purwa in fact sticks closely to the concept of Rama as the ideal person and hero even if his status as an avatara of Vishnu has been somewhat toned down. In this respect wayang kulit Kelantan has brought in significant changes. In the first instance, taking the events from the Kayangan, the antecedent of Seri Rama is Dewa Berembun, an almost human character rather than Vishnu, and so is his wife, Dewi Anjani. More in keeping with the character of Rawana, his future incarnation, Dewa Serajuk has a streak of violence in him, but what emerges most evidently is the theme of his sexual obsession with Lakshmi/Sri, and following that, during her several births until Rawana finally manages to kidnap her in the form of Sita Dewi. In some ways, then, the idea of reincarnation of a heavenly person as Rama is retained, even though he is not Vishnu and Rama is not treated as an avatara. Wayang kulit Kelantan puppeteers are, of course, unaware of the possible connections between their version of the Rama story and the classical epic as found in India or even in their own midst in the form of Hikayat Seri Rama. Like the Ramayana based material they use for their plots, their characters were developed and handed down by previous generations of dalang. 
It is noteworthy that, when it comes to wayang kulit Kelantan, there are two different versions of Seri Rama's character - the first in the prologue (bahagian dalang muda), and the second in the actual events from the epic that unfold on the puppeteer's screen. In the prologue Seri Rama is glorified in a song known as berbilang Seri Rama (words in praise of Seri Rama). He is presented as a perfect human being and an ideal king in keeping with the concept of the god-king (devaraja) which found traction amongst Southeast Asian communities influenced by Indian culture as well as the Malay concept of daulat or special charisma believed to be possessed by every raja and sultan. Once the well-established plot of the epic begins to unfold, however, Seri Rama, still the hero, is seen, despite his heroism, to have human weaknesses. There are many instances of this. During the marriage competition (sayembara), unable to shoot an arrow through the forty palm trees swaying from side to side he is clearly distraught. He eventually succeeds only with the assistance of Laksmana, who realizes the cause of the problem. Seri Rama manifests a clear lack of insight when, despite warnings from Laksmana he jumps into a pool of water with Sita Dewi; both of them end up as monkeys. Once again it is Laksmana who restores them to their original forms. At several crisis points during the great final war of the epic, Rama often shows his lack of judgment as well as his weaknesses.

On all occasions he requires assistance from Laksmana as shown in the examples above, but also from others, particularly Hanuman Kera Putih and Pak Dogol. If all of this does tarnish his image it is not to a serious extent. He remains a scholar, warrior, killer of demons and other obnoxious creatures since his early life and all along his fourteen-year exile with Laksmana and Sita Dewi. He is seen as a devoted husband to Sita Dewi. Yet there are certain lapses in his character. Apart from the examples already given those that show his impetuosity as well as his lack of clear judgment include the manner in which he misinterprets the characters of Sita Dewi, as well as Surpanakha/Siti Mayang, with whom, in some dalang narratives, he even gets married until she exposes her true character in a quarrel with Sita Dewi, leading to punishment not by Seri Rama but by Laksmana, in order to save the situation. Other significant situations are the fire test of Sita Dewi and her later banishment. Throughout all these incidents a significant weakening in Rama's character may be discerned, and the parallel strengthening of Laksmana as a heroic figure.

It is worthwhile taking notice that in many instances the basic events in the plot of the Ramayana as used in wayang kulit purwa and wayang kulit Kelantan are taken from original sources rather than invented by puppeteers, so that the weaknesses are already inbuilt into the character of Rama as developed in Hikayat Maharaja Wana, for instance. This becomes obvious from comparisons with equivalent episodes from other versions of the epic. Just to cite one instance - the banishment of Sita Dewi in Ramacharitmanasa and the wayang kulit Kelantan. In Tulsidas' work - Rama provides acceptable justification for Sita Dewi's departure - this being necessary or at least acceptable from a social, moral and religious perspective, so that Rama is totally absolved of any misdemeanor, not merely as an avatara of Vishnu, but God himself, a stance clearly maintained by Tulsidas. In sharp contrast to this, in the Kelantan version, the reasons given are irrational and the manner in which Sita Dewi is forced into exile is presented, one might say, in a rather crude manner. Upon discovery of Rawana's portrait, Rama ill-treats Sita Dewi, verbally as well as physically even to the extent of kicking her, before sentencing her to death. The scene is violent, almost brutal. The execution is to be carried out by Laksmana who is told that Sita Dewi is as ungrateful as a dog, and that, having killed her, Laksmana must produce her liver as evidence. Rama is certain she has the liver of a dog. He refuses to listen to any explanation or excuse from Laksmana; he even threatens Laksmana with banishment for defending Sita Dewi. In the end Laksmana has no choice but to take Sita Dewi away because of his devotion to his elder brother, and because Rama is king. Disobedience to a king or sultan in the Malay tradition is derhaka, a crime punishable with death. Traditionally this was carried out by piercing a keris right into the heart. When, unable to carry out the sentence, Laksmana sends Sita into the forest, he has to find a liver of some kind to avoid further problems with Rama. He kills a dog, sent by the gods just in the nick of time, a minor god in the shape of a dog. In Tulsidas' version, Sita Dewi goes into the forest as a personal desire, there being no coercion or pressure on her to leave. She is a perfect person and Rama is not seen as blameworthy. He cannot be, as a perfect being. 
Seri Rama in the Kelantan versions is more of a human hero rather than an avatara of Vishnu, or God himself. It appears from evidence that certain local puppeteers were aware of the status of Rama as avatara, but in general this idea has not been maintained due to the cleaning out of Hindu religious elements. Rama, in wayang kulit Kelantan then, is fully human, and as the son of a human king he is not the ideal figure of Hindu devotion or classical literature. Rama also appears in the branch stories (cerita ranting) of the Kelantan shadow play, but in these tales his character suffers further decline, with the tendency among puppeteers to transform him into philanderer, a Romeo-figure with the roving eye and the tendency to chase any woman at all no matter what her marital status, as long as she is desirable. This naturally leads to conflicts, at times physical, between Rama and a much-transformed Sita Dewi, presented in those tales in the mould of Galuh Chandra Kirana.

\section{Laksmana}

In Indian versions of the Ramayana, Laksmana is a younger half-brother of the hero, Rama, having the same father (Dasaratha) but a different mother (Sumitra). This changes somewhat in the Kelantan wayang kulit version of Rama stories. The two brothers go to the same teacher, a maharisi, for their early education, and both are involved in battles against demons to assist the sages, but, as mentioned earlier the sages are not well defined, so that there is no strong character equivalent to Viswamitra. Laksmana accompanies Seri Rama on the trip involving the sayembara for Sita Dewi's hand, and plays an important role in securing the victory for Laksmana, by straightening out the serpent (naga) on whose back the forty palm trees stand.

During their return journey, through Laksmana's wisdom, Seri Rama and Sita Dewi escape several attempts by the demon-king, Rawana, to harm them. The most crucial of these involves the one in which Rama and Sita Dewi are turned into monkeys, resulting in the birth of Hanuman Kera Putih. The encounter with Surpanakha, once again, shows Laksmana's strength of judgment, overcoming her efforts to tempt him, while Rama is deceived into marrying her despite Laksmana's warnings. This time he has to battle her and punishes her severely when she reveals her true form following a quarrel with, and then an attack on Sita Dewi. In the episode where Sita Dewi, tempted by the golden deer, sends Seri Rama off to catch the animal for her, Laksmana is appointed her protector. When, upon hearing Seri Rama's voice calling for help, she insists that Laksmana go to save her husband, he at first refuses. However, when she accuses him of wishing harm upon Rama, so that he could have her for himself, he does go over unwillingly into the forest, leaving her protected by a magic circle which he draws. In the rescue effort following her kidnapping as well as in the final battles preceding the defeat of Rawana, Laksmana has many important appearances.

In one of the final battles of the epic, Laksmana is pitched against the mighty Indrajit, the son of Rawana, whom he kills. In all versions of the epic, Laksmana's devotion, loyalty and courage are qualities that stand out. Indeed, they stand out so strongly that, as mentioned earlier in the discussion on Rama, Laksmana seems to outshine Rama. In some of the branch stories he does have his own adventures, as do Seri Rama and Sita Dewi; in those an altogether different Laksmana emerges.

\section{Conclusion}

It is clear, then, that drastic as well as interesting transformations have taken place in the principal characters of the Ramayana during its shift away firstly, from the classical Indian versions into Indonesia and Malaysia, and secondly, in their use in performances of the two principal genres of shadow play, the Javanese wayang kulit purwa and the Malaysian wayang kulit Kelantan. The principal factors involved in these changes are the multiple cultural influences coming from outside as well as from within the regional and local cultures. Above and beyond all this, a significant element in the transformation has certainly been the liberty available to the puppeteers to improvise, localize and in other ways to make the 
characters available to their audiences. These figures have thus, in some sense, been "brought down" to their level of appreciation and understanding.

Undoubtedly the levels in audience-sophistication are clear between Java and Kelantan as reflected in their respective shadow play styles. In general wayang kulit purwa is more refined than wayang kulit Kelantan, due to its emplacement within a well-defined and structured social environment compared to unsophisticated folk setting in which wayang kulit Kelantan thrived. These differences in social and cultural phenomena are certainly reflected in the manner in which their central characters have been developed. They are refreshing beings who belong, in a broad sense, to the same epic and yet live and breathe in two different traditional milieus.

\section{Endnotes}

${ }^{1}$ This is a revised version of a paper presented at the International Seminar on Oral Epics - Performing Art Forms - Ballads of South Asia, held at Osmania University, Hyderabad India, on 23-24 March 2015.

${ }^{2}$ For brief discussions of these items refer to entries in Ghulam-Sarwar Yousof, Dictionary of Traditional Southeast Asian Theatre (1994): 223-228.

3 There is no standard spelling for the names of Ramayana characters. For this paper they have been systematized as follows: Dewa Vishnu, Maharisi, Dasaratha, Seri Rama, Sita Dewi, Laksmana and Rawana. Where alternative names are used, they are given in the standard local spelling styles.

${ }^{4}$ In the Malay language a wat is a Thai-Buddhist temple, many of which are found in Thai villages or communities in northern Peninsular Malaysia. In this instance it suggests Thai-Buddhist influence in wayang kulit Kelantan.

${ }^{5}$ In Hikayat Seri Rama there is an alternative origin story for Rawana, in which his violent nature results in his being thrown out from Kayangan. But that episode is never used in wayang kulit Kelantan. See Rajantheran Muniandy, Hikayat Seri Rama, pp. 1-6.

${ }^{6}$ Although the stories connected with Rawana's obsession end at this point, the idea of the reincarnation of Dewi Sri does not. Indonesian puppeteers tell of the appearance of her reincarnation in the form of Subhadra, sister of Krishna and wife of Arjuna.

\section{Bibliography}

Ghulam-Sarwar Yousof. (1992). Panggung Semar: Aspects of Traditional Malay Theatre. Petaling Jaya, Malaysia: Tempo Publishing.

Ghulam-Sarwar Yousof. (1994). Dictionary of Traditional Southeast Asian Theatre. Kuala Lumpur: Oxford University Press .

Ghulam-Sarwar Yousof. (1997). The Malay Shadow Play: An Introduction. Penang, Malaysia: The Asian Centre Berhad.

Harshananda, Swami. (2012). A Concise Encyclopaedia of Hinduism. Bangalore: Ramakrishna Math. 
Kamban. (2002). The Kamba Ramayana. N.S. Jagannathan (Ed.). (P.S.Sundram, Trans). New Delhi: Penguin Books India. (Original work published in $12^{\text {th }}$ century).

Muniandy, R. (1995). Hikayat Seri Rama: Perbandingan Versi Melayu, Sanskrit dan Tamil. [Hikayat Seri Rama: A Comparison of the Malay, Sanskrit and Tamil Versions]. Kuala Lumpur: Dewan Bahasa dan Pustaka.

Rajagopalachari, C. (2012). Ramayana. Mumbai, India: Bharatiya Vidhya Bhavan.

Saran, M., \& Khanna, V. C. (2004). The Ramayana in Indonesia. Delhi: Ravi Dayan Publisher.

Sekretariat Nasional Pewayangan Indonesia. (1999). Ensiklopedi Wayang Indonesia. Jakarta: Sena Wangi.

Sweeney, A.P.L. (1972). The Rama Saga and the Malay Shadow Play. Kuala Lumpur: The National University of Malaysia Press.

Sweeney, A. (1972). The Ramayana and the Malay Shadow Play. Kuala Lumpur: National University of Malaysia Press.

Tulsidas. (1999). Shri Ramcaritmanasa. R.C.V. Prasad (Ed. and Trans.). Delhi: Motilal Banarsidas Publishers Pvt. Ltd. (Original work published in $16^{\text {th }}$ century).

Zieseniss, A. (1963). The Rama Saga in Malaysia, its Origin and Development. (P.W. Burch, Trans.). Singapore: Malaysian Sociological Research Institute. 